\title{
The Effect of Work-Family Enrichment on Career and Life Satisfaction of Women Entrepreneurs ${ }^{1}$
}

DOI: 10.26466/opus.913203

\author{
* \\ $\underline{\text { Esengül İplik* }}$ - İlksun Didem Ülbeği ** \\ * Doç. Dr., Adana Alparslan Türkeş Science and Technology University, Adana/Turkey \\ E-Mail: eiplik@atu.edu.tr \\ ORCID: $\quad$ 0000-0002-6000-1588 \\ ${ }^{* *}$ Doç Dr., Çukurova University, Adana/Turkey \\ E-Posta: idulbegi@cu.edu.tr \\ ORCID: $\quad$ 0000-0001-6905-2720
}

\begin{abstract}
Their roles in business and family life, which are two important areas of their life, are intertwined in the woman's life and these roles are in constant interaction. A positive or negative situation in one area may affect the other area and may have positive and negative effects depending on the situation. In this study conducted in this direction, a study was conducted on women entrepreneurs who played a large number of roles in the family and their jobs, and the relationships between job-family enrichment and life and career satisfaction of women entrepreneurs were examined. For this purpose, the data were collected from 336 women entrepreneurs operating in Adana using convenience-sampling method through surveys. After the questionnaire was prepared, necessary permissions were received from the Research and Publication Ethics Board of Adana Alparslan Türkeş Science and Technology University (2018/3-4) and it was applied between April 5 and May 5, 2019. Confirmatory factor analysis was used to reveal the structural validity of the scales used in the study, and the indirect relationships between the variables were analyzed with the structural equation model. The results obtained from the confirmatory factor analysis revealed that the model fits well. As a result of the path analysis conducted to reveal the direct and indirect effects between the variables, it was revealed that work-family enrichment was positively related to career and life satisfaction. Similarly, career satisfaction has a mediation role in the effect of work-family enrichment on life satisfaction.
\end{abstract}

Key words: Women Entrepreneurs, Work-Family Enrichment, Career Satisfaction, Life Satisfaction

\footnotetext{
${ }^{1}$ It was produced from the project numbered 1811304, supported by the Department of Scientific Research Projects of Adana Alparslan Türkeş Science and Technology University.
} 


\title{
İş-Aile Zenginleşmesinin Kadın Girişimcilerin Kariyer ve Yaşam Tatmini Üzerine Etkisi
}

\begin{abstract}
*
Öz

Yaşamın iki önemli alanın oluşturan iş ve aile içerisinde üstlenen roller kadının hayatında çoğu zaman iç içe geçmiştir ve bu roller sürekli etkileşim halindedir. Bir alanda yaşadığ̆ olumlu ya da olumsuz bir durum diğer alanı etkileyebilmekte ve duruma göre pozitif ve negatif etkide bulunabilmektedir. Bu doğrultuda gerçekleştirilen bu çalışmada, anne ve çalışan kadın olarak, aile içerisinde (ev işleri ve çocuk bakımı sorumlulukları) ve işlerinde çok sayıda rol üstlenen kadın girişimciler üzerinde bir araştırma yapılarak, kadın girişimcilerin yaşadıklan iş-aile zenginleşmesi ile yaşam ve kariyer tatminleri arasındaki ilişkiler incelenmiştir. Bu amaç doğrultusunda kolayda örnekleme yöntemiyle seçilen Adana'da faaliyet gösteren 336 kadın girişimciden anket yoluyla veri toplanmıştır. Anket hazırlandıktan sonra Adana Alparslan Türkeş Bilim ve Teknoloji Üniversitesi Bilimsel Araştırma ve Yayın Etiği Kurulu'ndan (2018/3-4) gerekli izinler alınmış ve 5 Nisan - 5 Mayıs 2019 tarihleri arasında uygulanmıştır. Çalışmada kullanılan ölçeklerin yapısal geçerliğini ortaya koymak amacıyla doğrulayıcı faktör analizi yapılmış değişkenler, arasındaki dolaylı ilişkiler ise yapısal eşitlik modeli ile analiz edilmiştir. Doğrulayıcı faktör analizi sonucu elde edilen değerler modelin iyi uyum să̆ladı̆̆ın ortaya koymaktadır. Değişkenler arasındaki doğrudan ve dolaylı etkileri ortaya koymak amacıyla yapılan analiz sonucunda iş-aile zenginleşmesinin kadın girişimcilerin kariyer ve yaşam tatmini ile pozitif iliş̧ili olduğu ortaya konulmuştur. Benzer şekilde, iş-aile zenginleşmesinin yaşam tatmini üzerindeki etkisinde kariyer tatmininin aracllk rolünün bulunduğu belirlenmiştir.
\end{abstract}

Anahtar Kelimeler: Kadın Girişimci, İş-Aile Zenginleşmesi, Kariyer Tatmini, Yaşam Tatmini. 


\section{Introduction}

One of the most important elements of a country's economic and social development is the increment of women's participation in the workforce. The acceleration of the women participation, who make up about half of the world's population, in business life, and the increment in the female labor force rate in the total workforce has been observed in recent years. However, women, whose participation in the business world has increased, face some problems both while entering the workforce and during their working life. Women are not hired at the employment stage, based on the thought that some jobs in society are more suitable only for men. Similarly, they may experience work-family conflicts based on the thought that they cannot fully fulfill their job responsibilities while fulfilling the roles of "womanhood and motherhood" imposed on them by society, and they may encounter problems such as preventing and not supporting their promotion in business life. While some women who cannot overcome these problems stay out of business life, some prefer to establish their own businesses (İplik and Budak, 2010).

The phenomenon of entrepreneurship, which is accepted as one of the most important dynamics of economic growth and development and has been developing rapidly since the 1980s, has come to the fore as an alternative career opportunity for women as well as men due to reasons such as overcoming the problems they face in business life and being financially independent. In recent years, the increase in women's contribution to the economy by establishing their own businesses has an important place in solving the unemployment problem and economic development in developing countries due to the creation of new employment opportunities.

Since women are facing the problem of balancing their roles in business and family life, which are two important areas of their lives, due to being increasingly involved in business life by establishing their own businesses, this topic has become a significant study subject that has attracted researchers' attention. In previous studies on work-family interaction, this interaction has been reviewed from two different perspectives. In most of the studies (Clark 2001; Saltzstein, Ting and Saltzstein 2001; Frone, 2003; Baltes, Clark and Chakrabarti, 2009), work- 
family interaction is addressed with a conflict perspective, which assumes that when individuals take on more than one role (such as work and family) and transfer their resources to one of the roles more, the conflict will take place between roles, and this will negatively affect their life quality.

On the other hand, Sieber (1974) and Marks (1977), who conducted studies on work-family interaction, questioned the conflict perspective by arguing that the achievements provided by different roles in more than one area may be more than the drawbacks. Accordingly, Sieber (1974) argued that the accumulation and resources gained from the roles assumed by an individual in one area of his life would positively affect the other area and thus provide enrichment. On the other hand, Marks (1977) argued that some roles taken by an individual could create an energy that can be used to develop his experiences in other roles. As a result of these different perspectives on work-family interaction, many different concepts such as positive spillover, facilitation, enhancement, and enrichment have been defined in the literature to define positive connections between work and family roles (Greenhaus and Powell, 2006; Paustian-Underdahl, Halbesleben, Carlson and Kacmar, 2013).

Although the current theory and research on the concept of workfamily enrichment are basically based on employees' experience in an organizational context, positive connections between work and family roles can also be experienced by entrepreneurs. In the entrepreneurship context, individuals' work and family areas are more intertwined than in the organizational employment context because entrepreneurs can more easily transfer or share resources between areas. It is possible for women, who assume responsibilities in both work and home life, to experience work-family enrichment as a result of the positive effects of different roles they assume while successfully fulfilling both responsibilities. Enrichment, which is based on the thought that achievements acquired in one of the work or family roles will provide opportunities such as increased prestige, income, and similar benefits that can help to perform better in other areas of life, is a situation that has positive effects on the physical and psychological well-being of women entrepreneurs. Therefore, positive links between work and family roles, which can be experienced more by entrepreneurs, are seen as an issue that needs further 
examination (Powell and Eddleston, 2013). In this context, uncovering the positive impact of work-family enrichment, which reflects the positive side of work-family interaction, on women entrepreneurs is critical in terms of raising the number of women entrepreneurs, which is seen as a vital component of economic growth, and for these women to have stronger businesses. Accordingly, work-family enrichment will be discussed in the context of women entrepreneurs who have many different roles in social life, and it is aimed to determine the effect of enrichment on the occupation and life satisfaction of women entrepreneurs.

\section{Theoretical Framework}

\section{Women Entrepreneurship}

Entrepreneurship, a complex and multifaceted phenomenon and whose importance in the global economy is increasing, has generally been considered a male-gender concept; that is, it has been pointed out that it has masculine connotations. For a long time, women entrepreneurs were invisible in research and the media due to this circumstance, which was allegedly caused by the stereotypical male existence of entrepreneurs (Ahl, 2006). However, in recent years, particularly with the growth of industry, increased labor demand, and rapid social change, women, who make up half of the population, have been able to break free from their traditional roles and step in business life. The desire to overcome barriers encountered in paid employment, as well as the government funding to increase the number of women entrepreneurs, have resulted in a significant increase in women's involvement in entrepreneurship, which was previously seen as a male-dominated activity. Despite this rising number of women entrepreneurs, women entrepreneurship remains less common than male entrepreneurship in almost every country in the world (Terrell and Troilo, 2010).

While support programs have been carried out to increase the number of women entrepreneurs in both developing and developed countries due to their roles in job creation, execution, and development as the main driving force of economic growth, many studies have been conducted to 
understand the factors driving this phenomenon theoretically. When the studies in the literature are examined, it is seen that there are different opinions about which women can or cannot be included in the definition of an entrepreneurial woman, and therefore there are many different definitions of women's entrepreneurship (Yetim, 2002, p. 82). While in the report published by OECD (2017; OECD Gender Data Portal), women entrepreneurs are defined as women who own and work in their own business, including businesses without legal personality and selfemployed, in the report published by UN (2018; Evidence and Data for Gender Equality (EDGE), it is defined as women who have direct control over a business they own alone or with other people.

There are some differences between the genders in terms of personality traits and job profile when deciding to start a new enterprise. The main difference between women and male entrepreneurs is that men have a much broader range of job profiles. Aside from that, women entrepreneurs vary from male entrepreneurs for a variety of reasons, including when they first started working, the challenges they face while establishing and maintaining their businesses, and so on. The vast majority of women around the world engage in entrepreneurial activities based merely on survival. According to this, rather than seizing a new opportunity, women are more likely to start their own businesses out of desperation, owing to a lack of other choices for generating income (Buttner ve Moore, 1997).

Some researchers (Hisrich and Brush, 1985; Stokes, Riger, and Sullivan, 1995) identified these forces that drive women to become entrepreneurs as push and pull factors. Pull factors are the Schumpeterian variables that attract women to entrepreneurship, such as self-determination, desire for wealth, and self-sufficiency. Push factors force women to escape poverty or become entrepreneurs in need of certain financial support or leave them out of the labor market because they need a more flexible work program to balance work and family life. In general, women may face discriminatory working situations based on gender, such as invisible barriers (Akpinar-Sposito, 2013), which prevent them from advancing in their careers, and wage disparities. These are commonly categorized as push factors. However, facing such different practices can also affect women's self-perception and confidence, and as a result, it can be 
evaluated within the scope of entrepreneurial pull factors that lead women to start their own business (Buttner and Moore, 1997).

When the literature on women entrepreneurship is examined, it is possible to come across different classifications on the typology of women entrepreneurs. Considering all these classifications, seven different "idealtypical" women entrepreneur profiles were determined by combining the best known classifications by Bruni, Gherardi and Poggio (2004, p.261262) as follows:

- "aimless" young women who start a business essentially as an alternative to unemployment;

- "success-oriented" young women, where entrepreneurship is not a more or less random or compulsory choice, but a long-term career strategy;

- "Strong success-oriented" women, often childless, who see entrepreneurship activity as an opportunity for greater professional success or as a tool to overcome career development barriers encountered in their previous organizations;

- "dualists" who have to reconcile work and family responsibilities and therefore seek a solution that gives them flexibility, often with substantial work experience;

- "Returning workers" or women (usually low-skilled) who have left their previous jobs to take care of their families and are motivated mainly by economic concerns or a desire to create space for self-actualization outside the family sphere;

- "Traditionalists" or women with family backgrounds where owning and managing a business is a longstanding tradition; and

- "Radicals" or women motivated by an anti-cultural opponent of traditional entrepreneurial values who create initiatives aimed at supporting women's interests in society.

In addition to the issues they face due to their gender, women entrepreneurs have to deal with many other issues that all entrepreneurs, male or female, face. The most significant issue confronting Turkish women who want to start their own businesses is their inability to obtain the required capital necessary to start their businesses. Although there are no legally discriminatory and preventive rules for women to use bank loans, high loan costs restrict the use of bank loans when starting a 
business. Another source of funding that women can use in the stage of starting their own businesses is the support provided by the state. Arrangements have been made in recent years to promote women's entrepreneurship as well. However, the funds allocated and the amount of information provided to women about the loan options are insufficient (Gürol, 2000). Another difficulty faced by entrepreneurs in general in Turkey is the heavy bureaucratic procedures and slow continuation of the process at the stage of starting a small-scale enterprise and registration. The excessive number of compulsory transactions, their length of time, practices such as mandatory donations, and frequent legislative changes are among the legal and bureaucratic obstacles that women entrepreneurs complain about. The procedures of starting a business being excessive and costly can create a deterrent effect on women who want to start their own business (İlter, 2008).

\section{Work-Family Enrichment}

In recent years, for individuals who assume different business and family life responsibilities, which are two important elements at the center of an individual's life, establishing a balance between these two areas has become a major life problem. Today's diverse family structures, such as single-parent households with rising divorce rates, dual-income families, and shifts and trends in business life, force people to assume multiple roles both at work and at home. Individuals are constantly faced with the dilemma of balancing their duties in these two aspects of their lives (work and family) as a result of these various roles placed on them. Since the positive (enrichment) or negative (conflict) relationship between work and family can have a variety of positive or negative organizational consequences, it has become a widely discussed topic in recent years in the management discipline (Nicklin and McNall, 2013; Shein and Chen, 2011).

Enrichment, one of the positive aspects of work and family interaction, is expressed as the degree to which an individual's experience in one role improves the quality of life in another role (Greenhouse and Powell, 2006). Traditional definitions of work-family enrichment have been based on role theory, which assumes that taking on multiple roles will lead to 
positive outcomes for individuals. When individuals take on a role, this role creates resources that can develop their experience in another role (Marks, 1977; Sieber, 1974). Hence, enrichment is the source of resources acquired in one area of life (work or family) contributing to the other area in terms of development, impact, capital, or productivity (Carlson, Hunter, Ferguson, and Whitten, 2011, p.847).

The concept of work-family enrichment was first discussed and defined within the framework of a theoretical model created by Greenhaus and Powell (2006) (Figure 1). Accordingly, Greenhaus and Powell (2006) suggested that enrichment occurs when the achievements of an individual in one of the work or family roles (Role A) increase the individual performance in the role $\mathrm{s} /$ he assumes in the other area (Role $\mathrm{B}$ ). According to the model, there are two paths that a source created in one area affects the performance and positive affectivity in the other area. The first of these paths, the instrumental path, emerges when the resources (skills and perspectives, flexibility, psychological and physical resources, social capital, and financial resources) obtained from one area are transferred directly to another role (arrow 1 in Figure 1) and positively affect the individual's performance in this role and leads to positive affectivity. On the emotional path, which is the second path of the model, a source produced in an area of life, first affects the positive affectivity in this area either directly (arrow 2) or indirectly through high performance in this role (arrows 3 and 4); This positive affectivity causes high performance (arrow 5) and positive affectivity (arrow 6) in the other area, respectively (Powell and Greenhaus, 2006, p.652).

According to work-family enrichment, which is considered to be one of the most important dimensions of work-family balance, participation in a work role can generate resources that energize the employee's family role and vice versa. Hence, work-family enrichment can occur bidirectional, as enriching experiences can occur both from work to family and from family to work. Accordingly, as working life can provide resource achievements resulting in improved individual functioning in the family area (work-family enrichment); family life can also provide resource achievements that lead to improved individual functioning in the workplace (enrichment from family to work) (Crouter, 1984; Barnett, Marshall, and Sayer, 1992; Carlson et al., 2011). 
1

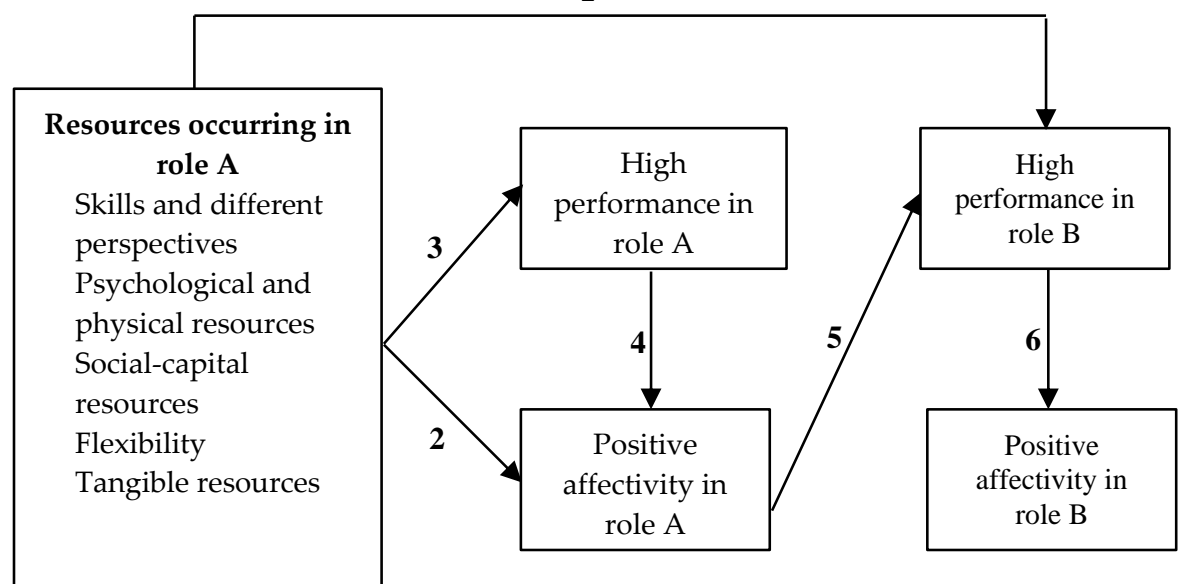

Figure 1. Work-family enrichment model (Powell and Greenhaus, 2006)

\section{Life Satisfaction}

Life satisfaction, which seen as a tool for people to live a better life, has become a topic that researchers have studied for many years to find appropriate definitions, and identify and measure the components of well-living, and many important books have been published in this field, such as The Quality of American Life (Campbell and Chetwynd-Hayes, 1976) and Social Indicators of Well-being (Andrews and Withey, 1976). In these books, concepts such as social relations, health, work-related conditions, personal well-being, freedom, moral values, and personality traits are emphasized as life satisfaction sources (Prasoon and Chaturvedi, 2016).

The concept of life satisfaction, first put forward by Neugarten in 1961, has been the subject of study in many studies until today and has been defined in different ways. It is seen that life satisfaction is not an easy concept to understand from many explanations and definitions made (Prasoon and Chaturvedi, 2016). Life satisfaction, which includes individuals' cognitive and judgmental perceptions about their subjective well-being, is defined by Shin and Johnson (1978, p.478) as "a comprehensive assessment of an individual's quality of life according to a set of criteria" (Diener, Emmons, Larsen and Grifin, 1985). Perceived 
quality of life relates to people's emotional beliefs and evaluations about their lives; that is, their attitudes towards their own lives, and such attitudes affect perceptions of quality of individual life spheres, such as the general quality of life as a whole, or the quality of working life and family life. The individual's general quality of life perception is associated with life satisfaction in psychology and psychiatry (Rice, Frone, and McFarlin, 1992). Satisfaction with one's life means being content with the current living conditions or the ability to meet the desires and needs related to life as a whole as he wants. Life satisfaction is a subjective and cognitive assessment of a person's quality of life and has been conceptualized as an important indicator of well-being (Anand and Arora, 2009).

The concept of life satisfaction, which expresses the satisfaction of the individual with his / her life as a whole (Diener et al., 1985), has become one of the most interesting topics in the field of organizational behaviour, based on the thought that the satisfaction experienced in the individual's life will also affect his / her behaviour in the organization. Business is an element that affects an individuals' quality of life and mental health and thus increases their productivity. Therefore, increasing the employee's well-being and improving his physical and psychological health provides significant benefits not only for the employees themselves but also for the employer. Employees' emotional well-being and their satisfaction with work and the workplace affect their behaviours of organizational citizenship, employee turnover rate, and individual performance (Hakanen and Schaufeli, 2012).

\section{Career Satisfaction}

Career is emerging as a remarkable research topic in the field of organizational behaviour, as it has a significant impact on the life of the employee. Everyone working in the organization strives for career success in the work environment. Career, first examined in detail in the study by Greenhaus, Parasuraman, and Wormley (1990), refers to the general course or progression of a person's working life. In a broader sense, career is defined as the work done by the individual in the past, advances in his 
profession, and work throughout his career (Uzonwanne and Nwanzu, 2017; Collin, 2006).

The career phenomenon, which is a concept handled by many different disciplines, represents the relationship of the individual with the organization in terms of human resources management, which aims to achieve the organization's goals by displaying effective performance through the employees. From this perspective, career plays a role in organizational reward and control systems, and career management means more than people managing their own careers. Accordingly, career management is defined as the process in which managers try to influence employees' careers by planning, supporting, monitoring their progress within the organization, and making certain interventions when necessary to align with the interests of both the individuals and the organization. To put it another way, career management, which refers to the career development of the employee within the organization, is about the organizational experiences that will motivate, develop and keep them in work, and is about determining the order of the work to be done in the organization and which skills should be given importance to develop (Collin, 2006).

Since the employee's subjective career satisfaction within the organization has become a necessary factor for career success, career satisfaction has come to the fore as the most discussed concept in career research in recent years (Park, 2018). Career satisfaction refers to the level of satisfaction of an individual with his career's internal and external aspects, such as wages, promotion, and personal development opportunities. It includes the employee's pleasure in doing his work, doing his job well, and being rewarded for his efforts (Sharma, 2019). Career satisfaction, which is defined as success and achievements acquired as a result of positive outcomes from work experience, includes the individual's subjective evaluation regarding all aspects of his career (Dries, Pepermans, and Carlier, 2008). Accordingly, individuals evaluate their careers based on the standards they determine subjectively, and they experience a sense of satisfaction as long as their work allows them to reach their general career goals, income goals, and career development goals. Hence, career satisfaction can also be expressed as an internal 
evaluation of the employee's career and a sense of professional success (Agrawal and Srivastava, 2018).

Employee career satisfaction has important consequences for organizations competing in today's more variable and competitive working environment to recruit and retain talented employees. Academic researchers define career satisfaction as an important indicator of career success, well-being, and adaptation (Coetzee and Bester, 2018). Individuals, who are highly committed to their work, and satisfied with their careers, as a whole are also happy in their lives (Joo and Lee, 2017).

\section{Relationships between Variables}

Managing the process of fulfilling the requirements of both work and family roles is seen as an ongoing problem for women entrepreneurs. Previous studies reveal that women experience more conflict than men between work and family roles and that this conflict has relatively more negative consequences on women's well-being. However, as an alternative to the perspective of conflict, which sees work and family as "enemies" to each other, the perspective of enrichment, which sees work and family as "allies," based on the view that taking on more than one role can be shared, expanded, and integrated between different fields of activity, has come to the fore. According to this view, for women who take on more than one role in work and family life, the enrichment process can be experienced intensely as well as conflict (Shelton, 2006).

Because of traditional gender roles, women seem more inclined to experience work-family enrichment than men. Men and women entrepreneurs make quite different connections between their work and family life that can affect their entrepreneurial success. While female entrepreneurs are not expected to have a border between work and family areas, male entrepreneurs are expected to separate family roles from work roles (Powell and Eddleston, 2013). Therefore, women entrepreneurs benefit more from work-family enrichment to benefit working life than male entrepreneurs, as they see their business and family life as two areas that are more holistic and affect each other more (Jennings and McDougald, 2007). 
Women entrepreneurs use the planning and communication skills they have developed while fulfilling their role in the family to manage their relations with employees, customers, and suppliers, thus increasing their work success. Besides, developing and transferring behaviours and skills between the work and family areas enables entrepreneurs to effectively manage their work and family roles by creating synergy between the two areas. In this case, the role assumed by the female entrepreneur in two different areas positively affects each other, and thus work-family enrichment occurs (Powell and Eddleston, 2013).

Taking on different roles in more than one area is a situation that creates positive effects in an individual's life as the resources acquired in one role enable personal development in another role, better skills, and a better mood. As women entrepreneurs who experience work-life enrichment can fulfill their role activities in all areas of their lives, their quality of life increases, and thus they become more satisfied with their jobs and lives (Greenhaus et al., 2003; p.515). Hence, work-family enrichment, which is based on the role theory suggesting that taking on more than one role can have positive outcomes for individuals, increases job satisfaction (Carlson, Grzywacz, and Kacmar, 2010; Carlson et al., 2006; McNall, Masuda, Nicklin, 2010; Carlson, Hunter, Ferguson, and Whitten, 2011), life satisfaction (Gorsy and Panwar, 2016; Azeez, Fapohunda, and Jayeoba, 2017; Gorsy and Panwar, 2016; Sakthivel and Jayakrishnan, 2018), work commitment, (Tims et al. 2015; De Klerk, Nel, and Koekemoer, 2015) and performance of the individuals (van Steenbergen \& Ellemers, 2009; Carlson, Kacmar, Zivnuska, Ferguson, and Whitten, 2011), while decreasing the overall stress level. In this context, considering these positive results of taking on more than one role in different areas of life for individuals, enrichment is an important factor that increases the health and well-being of the individual (Carlson et al., 2006; Stoddard and Madsen, 2007; van Steenbergen and Ellemers, 2009).

$\mathrm{H}_{1}$ : Work-family enrichment has a positive effect on the life satisfaction of women entrepreneurs.

Career satisfaction is a subjective condition that expresses employees' perceptions of satisfaction with their overall career goals and is associated with psychological success in both their work and family roles and their social relations success. The perception of psychological achievement 
stems from the individual's personal achievement of various goals such as success in life, inner peace and family happiness, and the pride they experience as a result. For most employees, a career means striking a balance between individual success and family success. According to this, if an individual chooses one of the roles he has assumed in two different areas, achieves only that role, and neglects the other area, the probability of experiencing work-family conflict will increase, which will negatively affect his / her perception of career success. On the other hand, the perception of psychological success will increase if the roles assumed in both work and family support each other and the individual succeeds in fulfilling these roles well (Ballout, 2008).

$\mathrm{H}_{2}$ : Work-family enrichment has a positive effect on the career satisfaction of women entrepreneurs.

Career satisfaction, which is a wider structure compared to job satisfaction and considered as a clear indicator of an individual's evaluation of his / her general area of work, is also considered as a precursor or component of an individual's overall quality of life or life satisfaction. In studies that examine how satisfaction felt in different areas of an individual's life such as family, work, and career, affect the overall life satisfaction, it is generally stated that there is a positive relationship between the two satisfaction and that satisfaction in one area will "spread" and affect the other. Because being satisfied with living spaces is expected to positively satisfy life satisfaction with life (Steiner and Truxillo, 1987). Accordingly, a career provides an individual's income to lead a good life, and success in his career increases self-confidence (Hagmaier, Abele, and Goebel, 2018; Lounsbury, Park, Sundstrom, Williamson, and Pemberton, 2004). Therefore, career success provides career satisfaction, and career satisfaction positively affects overall life satisfaction.

$\mathrm{H}_{3}$ : Career satisfaction has a positive effect on the life satisfaction of women entrepreneurs.

This study aims to examine the direct effect of work-family enrichment on the life satisfaction of women entrepreneurs as well as the indirect effect of career satisfaction. The above conceptual framework and empirical studies reveal the direct relationships between these variables. Based on the direct relationships between the variables, the following hypothesis was created considering that career satisfaction may have a 
mediating effect on the relationship between work-family enrichment and life satisfaction (see. Figure 1):

$\mathrm{H}_{4}$ : Career satisfaction has a mediating role in the effect of work-family enrichment on women entrepreneurs' life satisfaction.

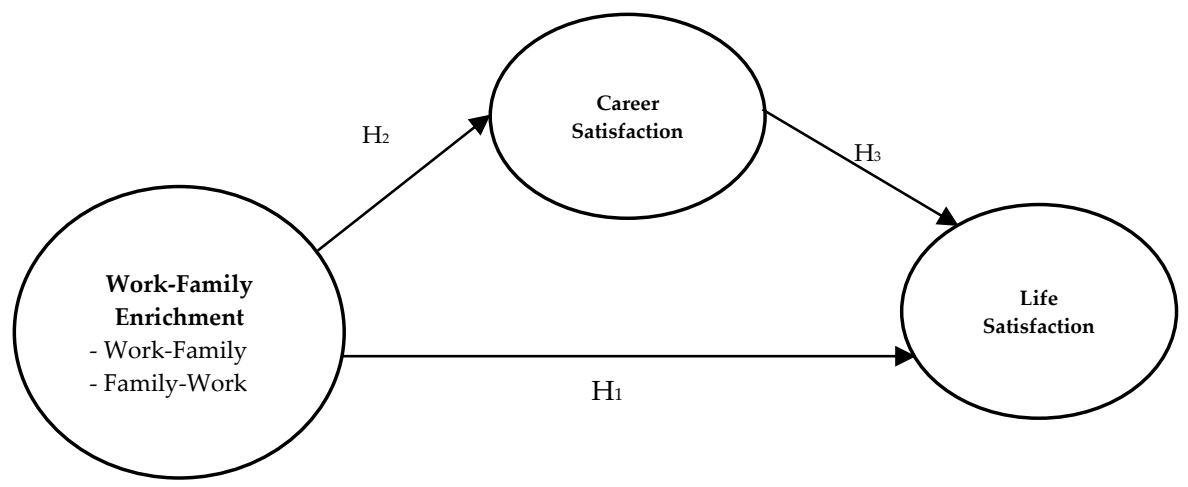

Figure 2. Research Model

\section{Method}

\section{Sampling}

The data used in the study's analysis was obtained by conducting a survey from women entrepreneurs operating in Adana with a convenience sampling method. After the questionnaire was prepared, necessary permissions were received from the Research and Publication Ethics Board of Adana Alparslan Türkeş Science and Technology University (2018/3-4) and it was applied between April 5 and May 5, 2019. A total of 340 questionnaires were distributed, and 4 of the returned questionnaires were not included in the study since they were not filled properly. Accordingly, analyses were carried out with a total of 336 questionnaires.

Among the women who answered the questionnaire, $61.9 \%$ are under the age of $40,50.9 \%$ are high school graduates, $63.7 \%$ are married, and $66.4 \%$ have at least one child. Considering the distribution of entrepreneur women by income levels, it was determined that $40.5 \%$ had an income ranged from $3001 \mathrm{TL}$ to $4500 \mathrm{TL}, 24.6 \%$ had an income of $4501 \mathrm{TL}$ to 6000 
$\mathrm{TL}$, and $18.2 \%$ was $6001 \mathrm{TL}$ and above. It is observed that there are no women entrepreneurs with an income below 1500 TL. $55.7 \%$ of the participants stated that they worked before becoming an entrepreneur. While $21.7 \%$ of working women stated that they were paid in their current job, $20.8 \%$ stated their previous occupation was a worker, and $11.3 \%$ selfemployed. When we look at the reasons that encourage women to start their own businesses, $34.8 \%$ stated that they set up their businesses to meet their family needs, $20.5 \%$ to be economically independent, and $19 \%$ to begin to work.

\section{Measures}

The 5-point Likert scale was used in the questionnaire form applied in the study. In this form, demographic questions were asked about work-family enrichment, life satisfaction and career satisfaction, and participants' age, working hours, entrepreneurship periods, and education levels.

For data collection, the work-family enrichment scale developed by Kacmar et al. (2014), the life satisfaction scale developed by Diener et al. (1985), and the career satisfaction scale developed by Greenhaus, Parasuraman, and Wormley (1990) were used.

\section{Process}

The Cronbach Alpha coefficient was taken into account in order to determine the internal consistency of the measurement tools used in the study. First, explanatory factor analysis was performed, and confirmatory factor analysis was performed to reveal the structural validity of the measurement model discussed. In addition, the relationships between the variables in the study were determined by correlation analysis. In testing the hypotheses put forward in the study, the effects between variables were determined using structural equation model analysis.

\section{Findings}

The Exploratory Factor Analysis method was used to reveal the validity of the study's scales. Before applying factor analysis to a data set, Kaiser- 
Meyer-Olkin (KMO) test should be performed to examine whether the data set is suitable for factor analysis. Accordingly, as a result of the analysis, KMO was determined as 0.871 , which indicates very good sample suitability. Besides, according to Bartlett's test of sphericity, it was determined that it was statistically significant at the $\chi^{2}=4075.67$, the degree of freedom 120, and $\mathrm{p}<0.01$ significance level. Accordingly, the current data set is multivariate normal distribution main mass and is suitable for factor analysis.

Table 1. Exploratory Factor Analysis

\begin{tabular}{|c|c|c|c|c|}
\hline & $\begin{array}{l}\text { Work-Family } \\
\text { Enrichment }\end{array}$ & $\begin{array}{l}\text { Family-Work } \\
\text { Enrichment }\end{array}$ & $\begin{array}{l}\text { Life } \\
\text { Satisfaction }\end{array}$ & $\begin{array}{l}\text { Career } \\
\text { Satisfaction }\end{array}$ \\
\hline \multicolumn{5}{|c|}{ Factor 1} \\
\hline \multicolumn{5}{|c|}{ Work-Family Enrichment } \\
\hline w1 & 0.817 & & & \\
\hline w2 & 0.857 & & & \\
\hline w3 & 0,859 & & & \\
\hline \multicolumn{5}{|l|}{ Factor 2: } \\
\hline \multicolumn{5}{|c|}{ Family-Work Enrichment } \\
\hline f4 & & 0.890 & & \\
\hline f5 & & 0.911 & & \\
\hline f6 & & 0,887 & & \\
\hline \multicolumn{5}{|c|}{ Factor 3: } \\
\hline \multicolumn{5}{|c|}{ Life Satisfaction } \\
\hline 17 & & & 0.827 & \\
\hline 18 & & & 0,866 & \\
\hline 19 & & & 0.860 & \\
\hline 110 & & & 0.727 & \\
\hline 111 & & & 0.792 & \\
\hline \multicolumn{5}{|c|}{ Factor 4} \\
\hline \multicolumn{5}{|c|}{ Career Satisfaction } \\
\hline c12 & & & & 0,774 \\
\hline c13 & & & & 0.820 \\
\hline c14 & & & & 0.874 \\
\hline c15 & & & & 0.871 \\
\hline c16 & & & & 0.689 \\
\hline $\begin{array}{l}\text { Explained } \\
\text { Variance }\end{array}$ & 16,081 & 17,691 & 21,839 & 22,084 \\
\hline
\end{tabular}

Principal components analysis, Varimax rotation method based on Kaiser normalization

KMO (Kaise-Meyer-Olkin) Sample size test $=0.871$

Bartlett's test of sphericity, $X^{2 n d}=4075,665 ; d f=120 i$ sig. $=0.0000$

Total explained variance $=77,695$

As seen in Table 1, 4 factors emerged in the study in total, and the eigenvalues of these factors took values 1 and greater than 1 . It was also 
found that these factors explain $77.69 \%$ of the variance. As a result of the analysis, factor loads took high values ranging from 0.689 to 0.911 . Factor loadings are the correlation of an item and an observed variable with the related factor. The square of the factor loading of the item in the factor shows how much of the variance in the relevant factor explains. A low factor loading average of an item means that that item is insufficient to explain the relevant factor. Factor loadings are generally recommended to be above 0.32 . Accordingly, factor loads between $0.32-0.5$ are classified as low, between 0.5-0.6 as good, between 0.6-0.7 as high, and between 0.7 and above as excellent factor loadings (Gürbüz and Şahin, 2015, p.304).

Confirmatory factor analysis was performed to determine the validity of the measurement model in the study. The maximum likelihood estimation method was used for this analysis. The coefficients revealed according to the related analysis findings are shown in Figure 1. It is seen that the goodness of fit values of the confirmatory factor analysis model fit very well $\left(\mathrm{X}^{2}=356,174 ; \mathrm{sd}=98 ; \mathrm{X}^{2} / \mathrm{sd}=3.634 ; \mathrm{p}<0.00 ; \mathrm{CFI}=0.936\right.$; TLI $=0.922 ; \mathrm{IFI}=0.936$; RMSEA $=0.089 ; \mathrm{SRMR}=0.0676)$. According to the findings, these values show that the model fits well.

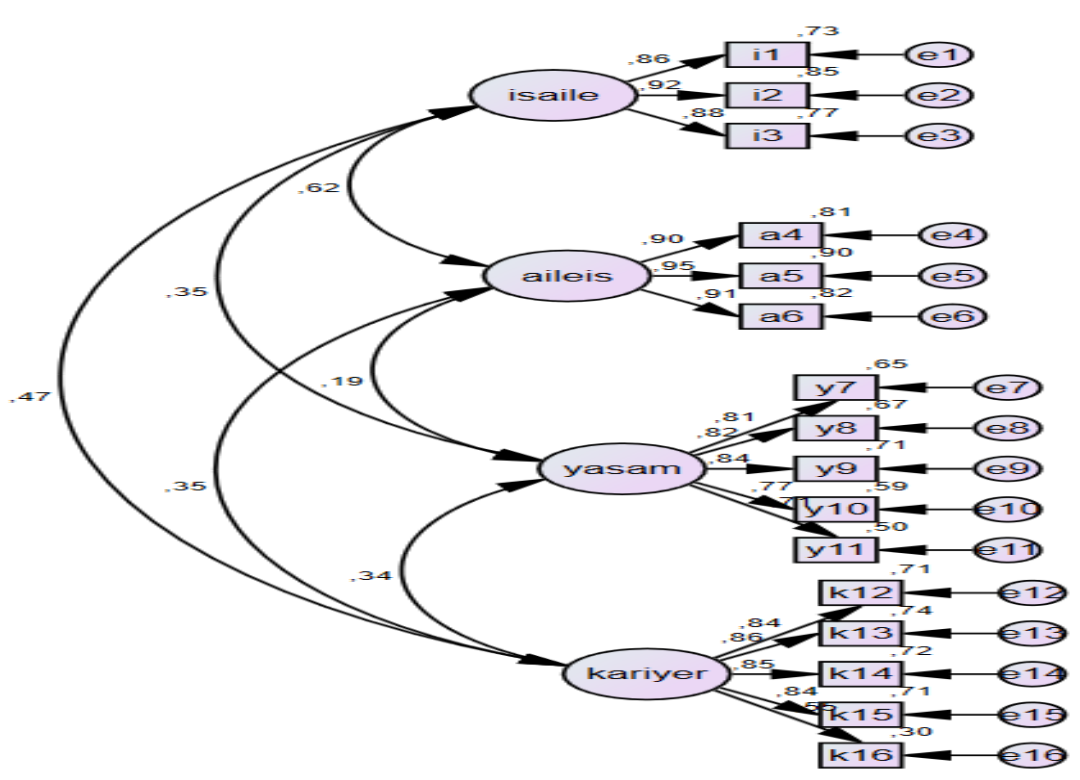

Figure 2. Confirmatory Factor Analysis 
The Cronbach alpha coefficient was taken into account in order to determine the reliability of the scales used in the study. As shown in Table 3 , the alpha coefficient of the work-family enrichment scale was determined as 0.915 , the family-work enrichment scale as 0.941 , the life satisfaction scale as 0.890 , and the career satisfaction scale as 0.886 . The fact that all of these values are above 0.70 (Hair, Black, Babin, and Anderson, 2010, p.125) shows that these measurement tools are reliable.

Correlation coefficients between variables considered within the scope of the study are given in Table 2. According to the findings mentioned above, the relationships between variables were obtained positively and significantly.

Table 2. Correlation Coefficients and Cronbach Alpha values

\begin{tabular}{lllll}
\hline & $\begin{array}{l}\text { Work-Family } \\
\text { Enrichment }\end{array}$ & $\begin{array}{l}\text { Family-Work } \\
\text { Enrichment }\end{array}$ & $\begin{array}{l}\text { Career } \\
\text { Satisfaction }\end{array}$ & Life Satisfaction \\
\hline $\begin{array}{l}\text { Work-Family } \\
\text { Enrichment }\end{array}$ & $(0.915)$ & & & \\
$\begin{array}{l}\text { Family-Work } \\
\text { Enrichment }\end{array}$ & $0.701^{* *}$ & $(0.941)$ & & \\
$\begin{array}{l}\text { Career } \\
\text { Satisfaction }\end{array}$ & $0.398^{* *}$ & $0.259^{* *}$ & $(0.886)$ & \\
Life Satisfaction & $0.322^{* *}$ & $0.240^{* *}$ & $0.323^{* *}$ & $(0.890)$ \\
\hline
\end{tabular}

${ }^{* *} p<0.01$

The structural equation model maximum likelihood was used in order to determine the effects within the framework of the research model presented in the study. Within the scope of the model, the coefficients were analyzed simultaneously. Figure 2 shows the effects and path coefficients revealed by this analysis. According to these findings, model goodness of fit values show very good fit $\left(X^{2}=356,174 ; \mathrm{sd}=98 ;\left(X^{2} / \mathrm{sd}=\right.\right.$ 3.634; $\mathrm{p}$ <0.00; CFI = 0.936; TLI = 0.922; IFI = 0.936; RMSEA = 0.089; SRMR $=0.0676)$. The results show that the model fits well. 


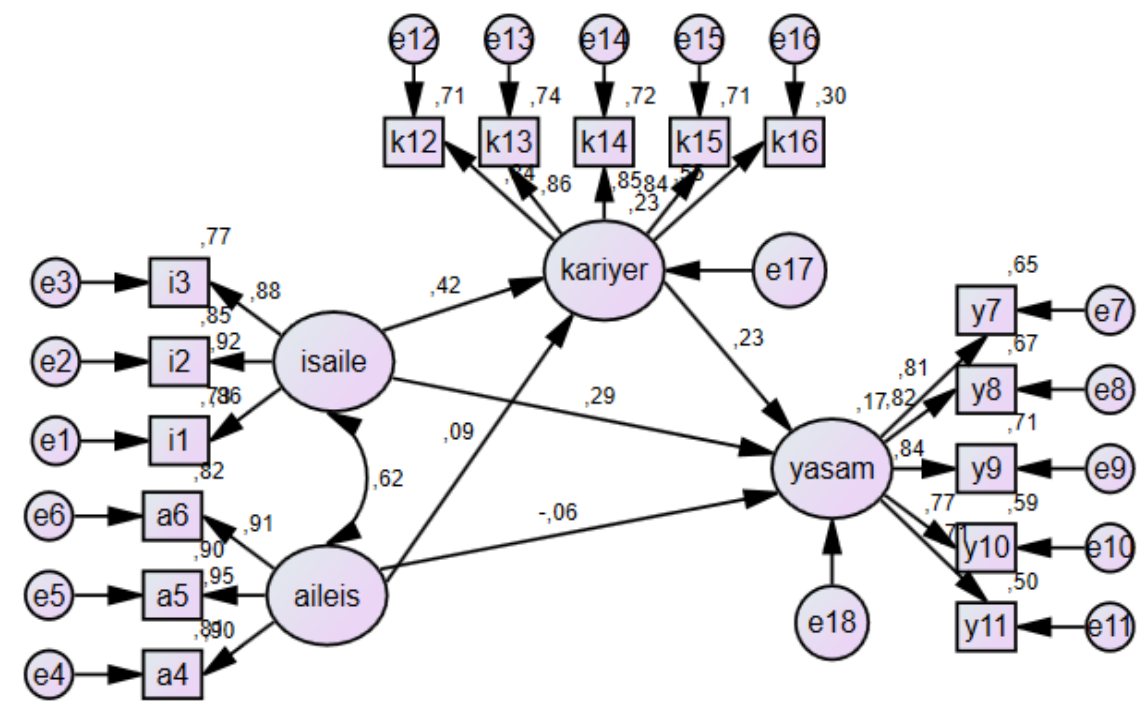

Figure 3. Research Model

In the study, it is seen that some of the hypotheses put forward regarding the effects of work-family enrichment and family-work enrichment on career satisfaction and life satisfaction within the scope of the model are supported, as can be seen in Figure 3. According to these findings, the effects of family-work enrichment on life satisfaction and career satisfaction were found to be insignificant. Based on this, the model has been revised and tested again.

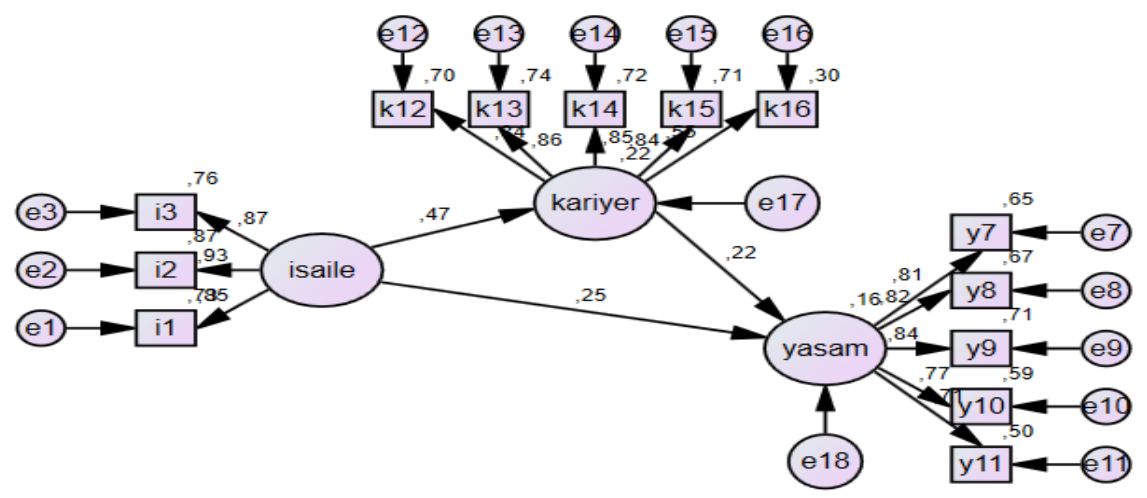

Figure 4. Revised Research Model 
In the study, the effects of work-family enrichment on career satisfaction and life satisfaction were discussed within the scope of the model, and the model is shown in Figure 4. According to these findings, the effects of work-family enrichment on life satisfaction and career satisfaction and significant positive effects of career satisfaction on life satisfaction were found. According to these findings, model goodness of fit values show very good fit $\left(X^{2}=289,186 ; s d=62 ; X^{2} / s d=4.664 ; p<0.00\right.$; $\mathrm{CFI}=0.923$; TLI $=0.903 ; \mathrm{IFI}=0.923$; RMSEA $=0.105 ; \mathrm{SRMR}=0.0674)$. The results show that the model fits well.

\section{Discussion and Conclusion}

Women entrepreneurship has been especially supported in many countries in recent years due to its positive contributions to countries' economic and social welfare, and the number of women entrepreneurs is rapidly increasing in the business world where male-dominated culture is widespread. The increasing number of women joining the workforce by establishing their own businesses has also led to an increased interest in the subject of maintaining the balance between women's work and personal lives. Maintaining the balance between job, career, and family demands have been accepted as one of the most important social issues since the 1990s (Parasuraman and Greenhaus, 1997).

Managing the roles assumed in both work and family in a balanced way is an important issue that women entrepreneurs are constantly confronted with, and that affects their in-work and off-work lives. Many previous studies have dealt with the interaction between work and family life from a conflict perspective based on the assumption that human time and energy are limited. These studies reveal that women experience more conflict than men between work and family roles and that this conflict has relatively more negative consequences on women's well-being. However, in recent years, studies examining the interaction between work and family life have suggested that the advantages of assuming different roles in more than one area may be more than its disadvantages and have focused on the concept of work-family enrichment as an alternative to the conflict perspective. Expressing that positive experience in a role assumed in one area of life (work or family) can positively affect the quality of life 
in another area (Greenhouse and Powell, 2006), enrichment positively affects the physical and psychological well-being of women and increases the individual's happiness, life satisfaction and perceived quality of life. In addition, work-family enrichment emerges as an important determinant of many positive work outcomes such as job satisfaction, career satisfaction, performance, and work commitment.

This study aimed to reveal the effect of work-life enrichment, which has important effects on the in-work and off-work lives of women who start their own business, on career and life satisfaction, and the role of career satisfaction in the relationship between work-life enrichment and life satisfaction Findings obtained from the study reveal that if women's positive experiences in one of the roles they have assumed in their job or their family positively affect their performance in the other role, their career satisfaction, and general life satisfaction will increase. The findings of previous studies on work-family enrichment (Keeton, Fenner, Johnson and Hayward, 2007; Gorsy and Panwar, 2016; Gorsy and Panwar, 2016; Azeez, Fapohunda, and Jayeoba, 2017; Sakthivel and Jayakrishnan, 2018) support these results on the relationship between work-family enrichment and career and life satisfaction.

Another result of the study is that if women entrepreneurs' satisfaction with their careers is high, their general life satisfaction will increase. Findings of previous studies (Beutell and Wittig-Berman, 1999; Lounsbury et al., 2004; Nemcek, 2007; Verbruggen and Sels, 2010) also support these results. In addition to these direct relationships, the mediating role of career satisfaction in the effect of work-family enrichment on life satisfaction was also discussed in the study. In the structural equation model analysis, the role of career satisfaction in the effect of enrichment in the form of work-family enrichment and family-work enrichment on life satisfaction was examined in the first model, but the effects of family-work enrichment on life satisfaction and career satisfaction were found to be insignificant. From this point of view, the family-business enrichment dimension was removed from the model, and the model was revised and tested again. According to the findings, it has been revealed that career satisfaction has a partial mediating effect on the relationship between the work-family enrichment dimension and life satisfaction. Accordingly, the effect of work-family enrichment on life satisfaction decreases with the 
mediating effect of career satisfaction but does not disappear completely. This result reveals that career satisfaction is not the only mediating variable in the relationships between work-family enrichment and life satisfaction and that other variables also have a mediating role in these relationships.

As in every study, this study also contains some limitations. Only the mediating role of career satisfaction in the relationship between workfamily enrichment and life satisfaction was examined in the study. However, the findings revealed that career satisfaction is not the only mediating variable in these relationships, and other variables also have a mediating role in these relationships. Hence, in future studies, it is recommended to test models to be established with different variables to reveal what variables may affect the relationship between these variables. Another limitation of the study is that it is a cross-sectional study. In future studies, measuring the variables in question repeatedly in a certain time period will be useful to reveal the differences that may occur in different periods.

With the perception of multiple roles assumed by women in different areas of their lives will not always have negative consequences and that the experience gained in one role can create enrichment by positively affecting the quality of life in the other role, women entrepreneurs will begin to question how they will use their experience in a role in another field, and as a result, the conflicts between the two areas will be reduced. Elimination of the conflict between the roles that the women entrepreneurs assume in their work and family life, which is one of the most important problems they are faced, will reflect on their work performance positively, and one of the reasons for failure in entrepreneurship will be eliminated. Despite all the limitations it possesses, this study, conducted with women entrepreneurs, is expected to contribute to the literature, as it focuses on the attitudes and behaviors of women entrepreneurs who have been studied in a very limited number of times, contrary to previous studies on women's entrepreneurial aspects. 


\section{References}

Agrawal, S. and Srivastava, S. (2018). Organizational commitment \& career satisfaction among women employees. The Indian Journal of Industrial Relations, 54(1), 132-145.

Ahl, H. (2006). Why research on women entrepreneurs needs new directions. Entrepreneurship: Theory E Practice, 30(5), 595-621.

Akpinar-Sposito, C. (2013). Career barriers for women executives and the Glass Ceiling Syndrome: The case study comparison between French and Turkish women executives. Procedia - Social and Behavioral Sciences, 75, 488-497.

Anand, M. and Arora, D. (2009). Burnout, life satisfaction and quality of life among executives of multinational companies. Journal of the Indian Academy of Applied Psychology, 35(1), 159-164.

Azeez, R. O., Fapohunda, T. M. and Jayeoba, F. I. (2017). Work-life balance and organisational commitment: Perceptions of working postgraduate students. BVIMSR's Journal of Management Research, 9(2), 178-188.

Ballout, H. I. (2008). Work-family conflict and career success: The effects of domain-specific determinants. Journal of Management Development, 27(5), 437-466.

Baltes, B. B., Clark, M. A. and Chakrabarti, M. (2009). Work-life balance: The roles of work-family conflict and work-family facilitation. In A. Lingley, S. Harrington, \& N. Page (Eds.), Handbook of Positive Psychology and Work. (p.491-521). New York: Oxford University Press, NY.

Barnett, R. C., Marshall, N. L. and Sayer, A. (1992). Positive-spillover effects from job to home: A closer look. Women \& Health, 19(2-3), 13-41.

Beutell, N. J. and Wittig-Berman, U. (1999). Predictors of work-family conflict and satisfaction with family, job, career, and life. Psychological Reports, 85, 893-903.

Bruni, A., Gherardi, S. and Poggio, B. (2004). Entrepreneur-mentality, gender and the study of women entrepreneurs. Journal of Organizational Change Management, 17(3), 256-268.

Buttner, E. H. and Moore, D. P. (1997). Women's organizational exodus to entrepreneurship: Self-reported motivations and correlates with success. Journal of Small Business Management, 35(1), 34-46.

Carlson, D. S., Grzywacz, J. G. and Kacmar, K. M. (2010). The relationship of schedule flexibility and outcomes via the work-family interface, Journal of Managerial Psychology, 25, 330-355. 
Carlson, D. S., Hunter, E. M., Ferguson, M. and Whitten, D. (2011). Work-family enrichment and satisfaction: Mediating processes and relative impact of originating and receiving domains. Journal of Management, 40(3), 845865.

Carlson, D., Kacmar, K. M., Zivnuska, S., Ferguson, M. and Whitten, D. (2011). Work-family enrichment and job performance: A constructive replication of affective events theory. Journal of Occupational Health Psychology, 16(3), 297-312.

Clark, S. C. (2001). Work cultures and work/family balance. Journal of Vocational Behavior, 58, 348-365.

Coetzee, M. and Bester, M. S. (2018). Probing the role of psychosocial career mechanisms in the harmonious work passion-career satisfaction link. Personnel Review, 48(5), 1135-1149.

Collin, A. (2006). Conceptualising the family-friendly career: The contribution of career theories and a systems approach. British Journal of Guidance and Counselling, 34(3), 295-307.

Crouter, A. C. (1984). Spillover from family to work: The neglected side of the work-family interface. Human Relations, 37(6), 425-441.

De Klerk, M., Nel, J. A. and Koekemoer, E. (2015). Work-to-Family enrichment: Influences of work resources, work engagement and satisfaction among employees within the South African context. Journal of Psychology in Africa, 25(6), 537-546.

Diener, E., Emmons, R. A., Larsen, R. J. and Grifin, S. (1985). The satisfaction with life scale. Journal of Personality Assessment, 49(1), 71-75.

Dries, N., Pepermans, R. and Carlier, O. (2008). Career success: Constructing a multidimensional model. Journal of Vocational Behavior, 73, 254-267.

Frone, M. R. (2003). Work-family balance. In J. C. Quick \& L. E. Tetrick (Eds.), Handbook of occupational health psychology (p.143-162). Washington, DC: American Psychological Association.

Gorsy, C. and Panwar, N. (2016). Work-life balance, life satisfaction and personality traits among teaching professionals. International Journal in Management and Social Science, 4(2), 98-105.

Greenhaus, J. H. and Powell, G. N. (2006). When work and family are allies: A theory of work-family enrichment. The Academy of Management Review, 31, 72-92. 
Greenhaus, J. H., Parasuraman, S. and Wormley, W. M. (1990). Effects of race on organizational experiences, job performance evaluations, and career outcomes. The Academy of Management Journal, 33(1), 64-86.

Gürbüz, S. and Şahin, F. (2017). Sosyal bilimlerde araştırma yöntemleri felsefe, yöntem, analiz (4. Baskı). Ankara: Seçkin Yayıncılık.

Gürol, M. A. (2000). Türkiye'de kadın girişimci ve küçük işletmesi: Firsatlar, sorunlar, beklentiler ve öneriler. Ankara: Atılım Üniversitesi Yayınları.

Hagmaier, T., Abele, A. E. and Goebel, K. (2018). How do career satisfaction and life satisfaction associate? Journal of Managerial Psychology, 33(2), 142160.

Hair, J. F. Jr., Black, W. C., Babin, B. J. and Anderson, R. E. (2013). Multivariate Data Analysis. Pearson International Edition, 7th Ed. US: Pearson Education Limited.

Hakanen, J. J. and Schaufeli, W. B. (2012). Do burnout and work engagement predict depressive symptoms and life satisfaction? A three-wave seven-year prospective study. Journal of Affective Disorders, 141, 415-424.

Hisrich, R. D. and Brush, C. G. (1985). Women and minority entrepreneurs: A comparative analysis. In J. A. Hornaday, E. B. Shils, J. A. Timmons, \& K. H. Vesper (Eds.), Frontiers of entrepreneurial research (p.566-587). Boston, MA: Babson College.

İlter, B. (2008). Girişimcilik sürecinde kadın girişimcilerin karşılaştıkları sorunların analizi: KAGIDER örneği, Yayınlanmamış Doktora Tezi. Afyon Kocatepe Üniversitesi, Afyonkarahisar.

İplik, E. and Budak, D. B. (2010). Kırsal alanda kadın girişimciliği. Toplumsal Gelişmede Türk ve Japon Kadının Eğitimi Sempozyumu, 06-08 Ekim 2010, Çanakkale, 280-298.

Jennings, J. E. and McDougald, M. S. (2007), Work-family interface experiences and coping strategies: Implications for entrepreneurship research and practice. The Academy of Management Review, 32(3), 747-760.

Joo, B. K. and Lee, I. (2017). Workplace happiness: work engagement, career satisfaction, and subjective well-being. Evidence-based HRM, 5(2), 206221.

Kacmar, K. M., Crawford, W. S., Carlson, D. S., Ferguson, M. and Whitten, D. (2014). A Short and Valid Measure of Work-Family Enrichment. Journal of Occupational Health Psychology, 19(1), 32-45. 
Keeton, K., Fenner, D. E., Johnson, T. R. B. and Hayward, R. A. (2007). Predictors of physician career satisfaction, work-life balance, and burnout. Obstetrics \& Gynecology, 109(4), 949-955.

Lounsbury, J. W., Park, S. H., Sundstrom, E., Williamson, J. M. and Pemberton, A. E. (2004). Personality, career satisfaction, and life satisfaction: Test of a directional model. Journal of Career Assessment, 12(4), 395-406.

Marks, S. R. (1977). Multiple roles and role strain: Some notes on human energy, time, and commitment. American Sociological Review, 42, 921-936.

McNall, L. A., Masuda, A. D. and Nicklin, J. M. (2010). Flexible work arrangements, job satisfaction, and turnover intentions: The mediating role of work-to-family enrichment. The Journal of Psychology, 144(1), 6181.

Nemcek, M. A. (2007). Registered nurses' self-nurturance and life and career satisfaction. AAOHN Journal, 55(8), 305-310.

Nicklin J. M. and McNall L. A. (2013). Work-Family enrichment, support, and satisfaction: A test of mediation, European Journal of Work and Organizational Psychology, 22(1), 67-77.

OECD, Gender Data Portal (2017). Entrepreneurship at a Glance 2017. Erişim Linki: $\quad$ https://www.oecd-ilibrary.org/docserver/entrepreneur aag-2017en.pdf?expires $=1617907885 \mathcal{E}$ id $=$ idEaccname $=$ guestEchecksum $=108$ B3F188 5D0753AA2F215777D61856B. Erişim Tarihi: 03.02.2021.

Parasuraman, S. and Greenhaus, J. H. (1997). Integrating work and family: Challenges and choices for a changing world. Westport, CT: Praeger Publishers.

Park, Y. (2018). Empirical investigation on the predictors of career satisfaction. Industrial and Commercial Training, 50(4), 165-171.

Paustian-Underdahl, S. C., Halbesleben, J. R. B., Carlson, D. S. and Kacmar, K. M. (2013). The work-family interface and promotability: Boundary integration as a double-edged sword. Journal of Management, 42(4), 960981.

Powell, G. N. and Eddleston, K. A. (2013). Linking family-to-business enrichment and support to entrepreneurial success: Do female and male entrepreneurs experience different outcomes? Journal of Business Venturing, 28, 261-280.

Powell, G. N. and Greenhaus, J. H. (2006). Is the opposite of positive negative?: Untangling the complex relationship between work-family enrichment and conflict. Career Development International, 11(7), 650-659. 
Prasoon, R. and Chaturvedi, K. R. (2016). Life satisfaction: A literature review. The Researcher-International Journal of Management Humanities and Social Sciences, 1(2), 25-32.

Rice, R. W., Frone, M. R. and McFarlin, D. B. (1992). Work-nonwork conflict and the perceived quality of life. Journal of Organizational Behavior, 13(2), 155-168.

Sakthivel, D. and Jayakrishnan, J. (2018). Work life balance and organizational commitment for nurses. Asian Journal of Business and Management Sciences, 2(5), 1-6.

Saltzstein, A. L., Ting, Y. and Saltzstein, G. H. (2001). Work-family balance and job satisfaction: The İmpact of family-friendly policies on attitudes of federal government employees. Public Administration Review, 61(4), 452467.

Sharma, S. (2019). Extrinsic rewards, occupational commitment, career entrenchment and career satisfaction of dentists. Asia Pacific Journal of Health Management, 14(1), 1-13.

Shein, J. and Chen, C. P. (2011). Work-Family enrichment: A research of positive transfer. Rotterdam: Sense Publishers.

Shelton, L. M. (2006). Female entrepreneurs, work-family conflict, and venture performance: New insights into the work-family interface. Journal of Small Business Management, 44(2), 285-297.

Shin, D. C. and Johnson, D. M. (1978). Avowed happiness as an overall assessment of the quality of life. Social Indicators Research, 5, 475-492.

Sieber, S. D. (1974). Toward a theory of role accumulation. American Sociological Review, 39, 567-578.

Steiner, D. D. and Truxillo, D. M. (1987). Another look at the job satisfactionlife satisfaction relationship: A test of the disaggregation hypothesis. Journal of Occupational Behaviour, 8, 71-77.

Stoddard, M. and Madsen, S. R. (2007). Toward an understanding of the link between work-family enrichment and health. Journal of Behavioral and Applied Management, 9(1), 2-15.

Stokes, J., Riger, S. and Sullivan, M. (1995). Measuring perceptions of the working environment for women in corporate settings. Psychology of Women Quarterly, 19, 533-549.

Terrell, K. and Troilo, M. (2010). Values and female entrepreneurship. International Journal of Gender and Entrepreneurship, 2(3), 260-286. 
Timms, C., Brough, P., O'Driscoll, M., Kalliath, T., Siu, O.-L., Sit, C. and Lo, D. (2015). Positive pathways to engaging workers: Work-Family enrichment as a predictor of work engagement. Asia Pacific Journal of Human Resources, 53, 490-510.

UN, Department of Economic and Social Affairs, Statistics Division (2018). Technical Report on Measuring Entrepreneurship: Lessons Learned from the EDGE Project. New York: United Nations. Erişim Linki: https://unstats.un.org/edge/publications/docs/Technical-Report-onEntrepreneurship.pdf. Erişim Tarihi: 03.02.2021.

Uzonwanne, F. C. and Nwanzu, C. L. (2017). Pay satisfaction and career satisfaction as predictors of organizational commitment among employee leaders of banks in North and Southwest Nigeria. Journal of Management Research, 17(1), 9-21.

Van Steenbergen, E. F. and Ellemers, N. (2009). Is managing the work-family interface worthwhile? Benefits for employee health and performance. Journal of Organizational Behaviour, 30, 617-642.

Verbruggen, M. and Sels, L. (2010). Social-cognitive factors affecting clients' career and life satisfaction after counseling. Journal of Career Assessment, 18(1), 3-15.

\section{Kaynakça Bilgisi / Citation Information}

İplik, E. and Ülbeği, İ. D. (2021). The effect of work-family enrichment on career and life satisfaction of women entrepreneurs. OPUSInternational Journal of Society Studies, 18(42), 5157-5186. DOI: 10.26466/opus.913203. 